\title{
PERLINDUNGAN HUKUM PEKERJA ALIH DAYA DI PERUSAHAAN PENYEDIA JASA PEKERJA PAILIT
}

\author{
Andre Azka Hanifan \\ Sudahnan \\ Fakultas Hukum Universitas Wijaya Kusuma Surabaya \\ e-mail:sudah_nan66@yahoo.com
}

\begin{abstract}
ABSTRAK
Pengalihan sebagian pekerjaan kepada perusahaan lain diperbolehkan oleh Undang-Undang Nomor 13 Tahun 2003 tentang Ketenagakerjaan sebagaimana diatur dalam Pasal 64 sampai dengan Pasal 66, dan mengenai kedudukan pekerja alih daya diperjelas dalam Putusan Mahkamah Konstitusi Nomor 27/PUU-IX/2011 tentang Sistem Penyerahaan Sebagian Pekerjaan Kepada Perusahaan Penyedia Jasa Pekerja kemudian ditindaklanjuti dengan Peraturan Menteri Tenaga Kerja Nomor 19 Tahun 2012 tentang Syarat-syarat Penyerahan Sebagian Pelaksanaan Pekerjaan Kepada Perusahaan Lain. Perusahaan Penyedia Jasa Pekerja tetap bertanggungjawab terhadap keberadaan pekerja alih daya meskipun perusahannya dalam keadaan pailit atau bankrut, dan pekerja tetap mendapatkan perlindungan hukum meskipun pekerja alih daya yang bersangkutan melakukan pekerjaan dengan Perjanjian Kerja Waktu Tertentu. Metode Penelitian ini menggunakan metode yuridis normatif, dengan pendekatan secara conceptual approach pendekatan konseptual dan statute approach pendekatan perundang-undangan. Kesimpulan dalam penelitian ini perusahaan penyedia jasa pekerja dalam keadaan pailit tetap harus bertanggungjawab kepada pekerja alih daya yang melakukan perjanjian kerja waktu tertentu sampai batas waktu yang telah ditentukan dan pekerja alih daya tetap mendapatkan perlindungan hukum sebagaimana yang telah ditentukan Undang-Undang.
\end{abstract}

Kata Kunci: pekerja alih daya, perusahaan penyedia jasa pekerja pailit.

\section{ABSTRACT}

The transfer of some of the work to another company permitted by the Act No.13 of 2003 onEmployment as stipulated in Article 64 through Article 66, and the power over the workers' status clarified in the Decision of the Constitutional Court. System penyerahaan 27/PUUIX/2011 about some of the work toWork services provider company then followed up by the Minister of Manpower No. 19 of 2012 on Submission Requirements partial implementation of the Employment of Other. Company Full Service Provider is responsible for the existence of outsourced workers even though his company in a state of bankruptcy or bankruptcy, and workers still get legal protection despite outsourcing workers concerneddo the job with Specific Time Work Agreement. Methods This study used a normative juridical method, the conceptual approach and the conceptual approach approach approach approach statute legislation. The conclusion of this research Workers Services Provider Company in a state of bankruptcy should still be accountable to the outsourced workers who perform labor agreement until a certain time limit specified time and labor overstill obtain legal protection as determined by law.

Keywords: labour outsourcing, bankrupt workers services provider company.

\section{PENDAHULUAN}

Pembangunan di bidang ketenagakerjaan berdasarkan atas asas pembangunan nasional, yaitu asas demokrasi, adil, dan merata. Hal ini dilakukan disebabkan pembangunan ketenagakerjaan dalam keberadaannya menyangkut multidimensi dan terkait terhadap beberapa pihak, yaitu pemerintah, 
pengusaha, dan pekerja, oleh karena itu pembangunan ketenagakerjaan harus dilakukan secara terpadu dan saling mendukung. Jadi asas hukum ketenagakerjaan adalah asas keterpaduan melalui koordinasi fungsional dalam lintas sektoral antara pusat dan daerah, disamping itu pula untuk meningkatkan daya saing terhadap perekonomian nasional, pemerintah Indonesia terus berupaya menata perekonomian di berbagai sektor, termasuk dalam sektor peningkatan kualitas maupun kuantitas sumber daya manusia Indonesia.Untuk mempercepat proses penataan tersebut pemerintah Indonesia terus mendorong seluruh perusahaan untuk mencari beberapa terobosan baru untuk dapat bersaing menghadapi ekonomi global dan salah satu terobosan yang dilakukan oleh perusahaan yaitu penyerahan sebagian pekerjaan terhadap perusahaan lain, terobosan itu dilakukan agar perusahaan benar-benar terfokus terhadap satu bidang saja yaitu manajemen perusahaan dalam menghadapi globalisasi ekonomi sedangkan bidang-bidang yang lain seperti pengadaan sumber daya manusia diserahkan kepada perusahaan lain untuk melakukan perekrutan, pembinaan dan pelatihan.

Perkembangan ekonomi yang terus berkembang di satu pihak dan menghadapi persaingan ekonomi global di lain pihak, maka pemerintah Indonesia terus melakukan penyesuaian terhadap kebijakan-kebijakan yang akan dikeluarkan sebagai tumpuan dasar dan salah satunya diundangkannya Undang-Undang Nomor 13 Tahun 2003 tentang Ketenagakerjaan (selanjutnya disebut UU Ketenagakerjaan, di dalam alinea pertama hingga alinea ketiga dalam penjelasan umum UU Ketenagakerjaan, dinyatakan bahwa pembangunan ketenagakerjaan sebagai bagian dari pembangunan nasional yang berlandaskan Pancasila dan UndangUndang Dasar 1945, dilaksanakan dalam kerangka peningkatan harkat, martabat dan harga diri tenaga kerja. Upaya ini juga diatur dalam Pasal 5 UU Ketenagakerjaan yang menyatakan, setiap tenaga kerja memiliki kesempatan yang sama tanpa diskriminasi beserta penghidupan yang layak bagi setiap pekerja, untuk menjamin kokohnya perekonomian dengan memperdayakan dan mendayagunakan para pekerja sebagaimana Pasal 59 dan 64-66 UU Ketenagakerjaan yang mengatur pekerja alih daya, dalam Pasal 64 dijelaskan bahwa perusahaan dapat penyerahan sebagian pelaksanaan pekerjaan kepada perusahaan lainnya melalui perjanjian pemborongan pekerja atau penyediaan jasa pekerja, untuk memperjelas terhadap batasan regulasi penyerahan sebagian pekerjaan terhadap perusahaan lain tersebut kemudian Pemerintah di bawah Kementerian Tenaga Kerja menindaklanjuti dengan mengeluarkan PerMenTrans Nomor 19 Tahun 2012 tentang Syarat-syarat Penyerahan Sebagian Pelaksanaan kepada Perusahaan Lain.

Penyerahan sebagian pelaksanaan pekerjaan kepada perusahaan lain dengan melalui pemborongan pekerjaan yang menitikberatkan dengan perjanjian hubungan kerja terhadap pekerja alih daya tentang jenis, jangka waktu, dan skema terhadap pelaksanaannya sedangkan penyerahan sebagian pelaksanaan pekerjaan kepada perusahaan lain melalui penyediaan jasa pekerja yang menitikberatkan dengan perjanjian hubungan kerja terhadap jasa pekerja yakni sesuai dengan sifat pemberian kerja yang dilakukan oleh pemberi kerja baik secara langsung ataupun secara tidak langsung, sedangkan perlindungan kerja terhadap pekerja alih daya merupakan tanggung jawab penyedia jasa pekerja meskipun pekerja alih daya ditempatkan di perusahaan pemberi kerja. UU Ketenagakerjaan telah menegaskan bahwa perlindungan kerja dan syarat-syarat kerja sekurang-kurangnya harus sama dengan pekerja di perusahaan pemberi kerja tidak terkecuali pekerja alih daya, namun menurut para pengamat, dalam prakteknya pekerja alih daya selama ini masih cenderung merugikan pihak pekerja alih daya. Kerugian ini antara lain disebabkan hubungan kerja yang pada umumnya bersifat tidak tetap atau bersifat kontrak, jaminan sosial yang hanya sebatas minimal, dan jaminan pengembangan karir tidak ada (Adrian Sutedi, 2009:219). Sehingga dalam keadaan seperti itu pelaksanaan pekerja alih daya dapat menyebabkan sengsara kepada pekerja dan membuat kaburnya hubungan industrial antara pekerja dengan perusahaan dan untuk mendapatkan perlindungan hukum yang sama dengan pekerja yang berada di perusahaan pemberi kerja hanya isapan jempol saja. Pelaksanaan pekerja alih daya banyak dilakukan oleh perusahaan dengan tujuan untuk menekan biaya pekerja (labour cost) dengan memperkecil bahkan menghilangkan perlindungan dan syarat kerja yang diberikan jauh di bawah dari yang seharusnya diberikan sehingga sangat merugikan pekerja (Evi Rosmanasari, 2008:9).

Sistem alih daya yang diserahkan kepada pihak lain yang dilakukan oleh pemberi kerja semata-mata agar pemberi kerja dapat memfokuskan diri terhadap manajemen perusahaan, sistem yang semula bertujuan baik tersebut telah banyak menimbulkan polemik pada 
saat sekarang karena secara fakta lapangan banyak dilakukan dalam prakteknya dengan tidak benar terhadap ketentuan-ketentuan perjanjian kerja yang sebenarnya, baik yang dilakukan oleh perusahaan penyedia jasa pekerja ataupun yang dilakukan oleh perusahaan pemberi kerja, sehingga menyebabkan posisi pekerja alih daya berada pada posisi yang sangat lemah untuk memperjuangkan hak-haknya sebagai pekerja sebagaimana yang telah diatur dalam undangundang, disamping itu pekerja alih daya tambah tidak berdaya lagi dengan bertambahnya umur dan lemahnya skill yang dimiliki untuk mendapatkan pekerjaan yang lain sangat menemui kesulitan karena kurangnya kemampuan atau keahlian bahkan tidak adanya kemampuan dalam bidang pekerjaan dimaksud yang menyebabkan daya tawar kerja rendah. Berdasarkan Putusan Mahkamah Konstitusi Nomor 27/PUU-IX/ 2011 dalam amar putusan Mahkamah Konstitusi (selanjutnya disingkat MK) yang mengabulkan sebagian uji materil yaitu Pasal 65 ayat (7) dan Pasal 66 ayat (2) huruf b dinyatakan inkonstitusional dan tidak mempunyai kekuatan hukum lagi. Maka pekerja alih daya yang ditempatkan di perusahaan pemberi kerja yang menitikberatkan atas perjanjian kerja waktu tertentu mengalami suatu perubahan sehingga dapat membawa perbaikan terhadap pelaksanaan dan ketaatan terhadap ketentuan-ketentuan hukum tentang pekerja alih daya.

Menurut ketentuan hukum tentang jenis pekerjaan yang dapat diserahkan kepada pihak lain disyaratkan berupa pekerjaan yang tidak berkaitan dengan bisnis utama perusahaan pemberi kerja, maka pekerja alih daya adalah solusi yang tepat dengan melakukan perjanjian kerjasama dengan perusahaan penyedia jasa pekerja untuk mendistribusikan pekerja alih daya ke perusahaan pemberi kerja dengan perjanjian kerja waktu tertentu, menurut para ahli yaitu semacam Perjanjian Kerja Waktu Tertentu (selanjutnya disebut PKWT) yaitu perjanjian kerja antara pekerja dengan pengusaha untuk mengadakan hubungan kerja dalam waktu tertentu atau untuk pekerjaan tertentu disebut juga dengan PKWT (F.X. Djumialdji, 2008:11). Secara limitatif, Pasal 59 menyebutkan bahwa PKWT hanya dapat diterapkan untuk pekerjaan tertentu yang menurut jenis, sifat dan kegiatan pekerjaannya akan selesai dalam waktu tertentu, yaitu pekerjaan yang sekali selesai atau yang sementara sifatnya, pekerjaan yang diperkirakan penyelesaiannya dalam waktu yang tidak terlalu lama, paling lama 3 tahun, pekerjaan yang bersifat musiman dan pekerjaan yang berhubungan dengan produk baru, atau produk tambahan yang masih dalam percobaan atau penjajagan ( $R$. Goenawan Oetomo, 2004:18).

Adanya model kontrak terhadap pekerja alih daya memberikan peluang dan memunculkan sengketa perburuhan bila penerapan pekerja alih daya tidak sesuai dengan peraturan hukum yang berlaku, hal ini juga terjadi karena negara Indonesia belum memiliki perangkat hukum yang khusus mengatur mengenai status pekerja dari perusahaan penyedia jasa. Konfllik hubungan kerja ini bahkan terus berlanjut hingga terjadi perselisihan hubungan industrial yang dibawa hingga tingkat Kasasi (RR Ani Wijayati, 2004: 65). Berdasarkan Undang-Undang Ketenagakerjaan istilah yang digunakan perjanjian pemborongan pekerjaan atau penyedia jasa pekerja dalam Pasal 64 menyebutkan perusahaan dapat menyerahkan sebagian pelaksanaan perkerjaan kepada perusahaan lainnya melalui perjanjian pemborongan pekerja atau penyedia jasa pekerja yang dibuat secara tertulis (Lalu Husni, 2012:189), hal ini juga diatur dalam Pasal 27 ayat (1) Peraturan Menteri Tenaga Kerja Nomor 19 Tahun 2012 tentang Syarat-syarat Penempatan Tenaga Kerja. Pekerjaan yang dapat diserahkan untuk pekerja alih daya adalah: Dilakukan secara terpisah dari kegiatan utama; Dilakukan dengan perintah langsung atau tidak langsung dari pemberi kerja; Merupakan kegiatan penunjang perusahaan secara keseluruhan; serta Tidak menghambat produksi secara langsung (Lalu Husni, 2012:189).

Perusahaan penyedia jasa pekerja juga harus mempunyai izin untuk menjalankan kegiatannya sebagai perusahaan penyedia jasa pekerja hal ini diatur dalam Pasal 19 Peraturan Menteri Tenaga Kerja Nomor 19 Tahun 2012 menyebutkan pekerjaan dari perusahaan pemberi pekerjaan kedua belah pihak harus membuat perjanjian tertulis sekurang-kurangnya memuat: 1 . Jenis pekerjaan yang akan dilakukan oleh pekerja buruh dari perusahaan penyedia jasa; 2 . Penegasan bahwa dalam melaksananakan pekerjaan sebagaimana dimaksud huruf 1, hubungan kerja yang terjadi adalah antara perusahaan penyedia jasa dengan pekerja yang di pekerjakan perusahaan penyedia jasa sehingga perlindungan, upah dan kesejahteraan, syarat-syarat kerja perselisian yang timbul menjadi tanggung jawab penyedia jasa pekerja; 3 . Penegasan bahwa perusahaan penyedia jasa pekerja bersedia menerima pekerja dari perusahaan penyedia jasa pekerja sebelumnya 
untuk jenis-jenis pekerjaan yang terus-menerus ada di perusahaan pemberi kerja, dalam hal terjadi penggantian perusahaan penyedia jasa pekerja (Lalu Husni, 2012:191-192).

Suatu perjanjian tertulis yang dilakukan antara perusahaan pemberi kerja dan penyedia jasa pekerja untuk menyetujui suatu perjanjian yang akan dibuat dan hal-hal apa saja yang akan dilakukan atau tidak akan dilakukan biasanya terdapat di dalam MoU dan SoP yang dibuat antara perusahaan tersebut untuk saling melakukan kerjasama dalam bidang ketenagakerjaan khususnya untuk mendapatkan pekerja alih daya yang dipekerjakan di perusahaan pemberi kerja. Sistem perjanjian yang diajukan oleh perusahaan penyedia jasa pekerja yang berbentuk pekerja alih daya pada umumnya dengan sistem perjanjian kerja waktu tertentu, bila diperhatikan dengan seksama dengan menempatkan pekerja alih daya dengan waktu yang singkat sulit untuk mendapatkan produksi atau hasil yang baik, sehingga penerapan penempatan pekerja alih daya dengan waktu yang singkat akan berimbas pada daya produktifitas seseorang untuk memberikan mutu dan kualitasnya kepada perusahaan, seharusnya perusahaan memberikan waktu yang cukup. Juga tidak menutup kemungkinan terhadap perjanjian kerja sama yang dilakukan oleh pemberi kerja dan penyedia jasa pekerja sudah berakhir tetapi kadangkala objek pekerjaannya masih ada di perusahaan pemberi kerja, maka keberadaan pekerja alih daya harus berakhir atau berhenti atau harus keluar dari perusahaan pemberi kerja karena pekerja alih daya tidak mempunyai hubungan kerja lagi dengan perusahaan pemberi kerja.

Perlindungan hukum bagi pekerja alih daya sepenuhnya berada dalam naungan perusahaan penyedia jasa pekerja disebabkan pekerja melakukan perjanjian kerja dengan perusahaan penyedia jasa pekerja, apabila suatu saat terjadinya kepailitan yang dialami oleh pihak penyedia jasa pekerja dan tidak mampu lagi mengelola pekerja yang berada dalam naungannya, maka keberadaan pekerja alih daya dimaksud tidak serta merta berakhir tetapi pekerja alih daya dimaksud tetap mendapatkan perlindungan hukum untuk menerima seluruh hak-hak dan status pekerja alih daya yang harus di perjuangkan untuk mendapatkan apa yang seharusnya didapatkan sebagaimana dimaksud dalam Pasal 39 ayat (1), (2) Undang-Undang Nomor 37 tahun 2004 tentang Kepailitan (selanjutnya disebut UU Kepailitan) dan Pasal 95 ayat (4) UU Ketenagakerjaan yang menyatakan, dalam hal perusahaan dinyatakan pailit atau dilikuidasi berdasarkan peraturan perundangundangan yang berlaku, maka upah dan hak-hak lainnya dari pekerja atau buruh merupakan utang yang didahulukan pembayarannya.

Perusahaan yang mengalami keadaan pailit ini disebabkan oleh kurang baiknya manajemen perusahaaan penyedia jasa pekerja itu sendiri dan banyaknya pengeluaran terhadap biaya-biaya serta kurangnya pendapatan, inilah yang akan menyebabkan perusahaan penyedia jasa pekerja melakukan pemutusan hubungan kerja secara sepihak meskipun pekerjaan di perusahaan pemberi kerja masih ada dan perjanjian hubungan kerja dengan perusahaan penyedia jasa belum berakhir disebabkan perusahaan mengalami pailit, menyebabkan tidak stabilnya pengelolaan terhadap perusahaan dan akhirnya ketidakpercayaan kepada perusahaan penyedia jasa pekerja oleh perusahaan pemberi kerja dan akhirnya berakibat terhadap tenaga kerja yang ditempatkan di perusahaan pemberi kerja yang harus keluar meskipun perjanjian kerja dengan perusahaan penyedia jasa pekerja belum berakhir.

Penyelesaian kepailitan terhadap perusahaan di satu pihak dan banyak kasus tenaga kerja yang di Pemutusan Hubungan Kerja (selanjutnya disingkat PHK) yang mencuat di media masa atau media pertelevisian di lain pihak yang mengangkat kasus dimana hak suatu pegawai diabaikan oleh perusahaan yang mengalami pailit hal ini sontak akan memunculkan opini-opini yang negatif bahwa suatu perusahaan tidak dapat memanusiakan manusia dan tidak bertanggungjawab hanya persoalan pesangon karyawan yang di PHK karena perusahaan mengalami keadaan pailit atau bangkrut, sehingga sisa upah yang seharusnya masih diterima tidak dapat direalisasikan oleh perusahaan kepada pekerjanya. UU Kepailitan telah mengatur peletakan sita umum atas semua kekayaan debitur yang mengalami keadaan pailit yang pengurusannya dan pemberesannya dilakukan oleh kurator di bawah pengawasan hakim pengawas, menurut Retno Wulan, kepailitan adalah eksekusi massal yang ditetapkan dengan keputusan hakim yang berlaku serta merta dengan melakukan penyitaan umum atas semua harta si pailit baik yang ada pada waktu pailit maupun diperoleh selama kepailitan.

Nasib para pekerja alih daya harus tetap menjadi tanggung jawab perusahaan penyedia jasa pekerja yang memperkerjakannya untuk melindungi semua hak-hak pekerja alih daya yang belum terbayar atau bahkan yang terpaksa diberhentikan sebelum 
masa kontraknya berakhir disebabkan perusahaan mengalami keadaan pailit, UU Ketenagakerjaan jo UU Kepailitan jo Putusan MK No. 27/PUU-IX/2011 jo PerMenTrans No. 19 Tahun 2012 tentang SyaratSyarat Penyerahan Pekerjaan Kepada Perusahaan Lain, pekerja alih daya harus mendapatkan perlindungan hukum dan penyelesaian terhadap hak-haknya dari perusahaan penyedia jasa pekerja yang mengalami keadaan pailit. Berdasarkan latar belakang permasalahan di atas, bagaimana status hukum dan penyelesaian pekerja alih daya di perusahaan penyedia jasa pekerja yang mengalami keadaan pailit.

\section{PEMBAHASAN}

Perusahaan penyedia jasa yang mengalami keadaan pailit atau bangkrut kedudukan pekerja alih daya merupakan kreditor privilege atau istimewa, Sehingga upah atau hak lainnya dari pekerja alih daya menjadi utang dari perusahaan penyedia jasa pekerja yang harus didahulukan. Menurut penulis para pekerja yang terkena pemutusan hubungan kerja karena perusahaan penyedia jasa mengalami keadaan pailit masih mempunyai hak untuk menuntut kepada perusahaan penyedia jasa pekerja untuk memberikan upah yang masih atau belum diberikan atau pesangon dan penghargaan yang harus diberikan terlebih dahulu dari kreditor lainnya dan hal ini menyangkut kehidupan atau kesejahteraan para pekerja alih daya itu sendiri untuk mendapatkan haknya yang semestinya, berdasarkan Pasal 95 ayat (4) UU Ketenagakerjaan jo Pasal 13 jo Pasal 28 PerMenTrans No. 19 Tahun 2012 tentang Syarat-Syarat Penyerahan Sebagian Pelaksanaan Pekerjaan Kepada Perusahaan Lain jo Putusan MK No. 27/PUU-IX/2011 tentang Sistem Pekerja Alih Daya, Hak-hak para pekerja alih daya tetap melekat sebagaimana semestinya sebelum adanya pailit.

Pekerja alih daya yang ditempatkan dalam perusahaan pemberi kerja seringkali tidak sama dalam penerapannya terhadap beberapa hak yang seharusnya diterima sebagaimana yang diberikan kepada pekerja yang berada di perusahaan pemberi kerja, sehingga para pekerja sering melakukan demo untuk menyuarakan hak-haknya agar disamakan dan tidak ada diskriminasi dalam pemberian hak-haknya karena sifat dan bentuk pekerjaannya sama. Menurut penulis kedudukan para pekerja alih daya dan pekerja yang melakukan hubungan kerja langsung dengan perusahaan pemberi kerja kedudukan pekerjanya sama serta hak-hak juga sama yang harus diterima oleh pekerja yang bekerja di perusahaan pemberi kerja, apabila di perusahaan pemberi kerja mengalami keadaan pailit maka pekerja yang diangkat secara langsung dan melakukan hubungan kerja dengan perusahaan pemberi kerja akan mendapatkan perlindungan hukum terhadap hak-hak yang harus diterima, demikian juga terhadap pekerja yang melakukan hubungan kerja dengan perusahaan penyedia jasa pekerja yang mengalami keadaan pailit juga akan mendapatkan perlindungan hukum terhadap hak-hak yang harus diterima, tetapi hal ini tergantung terhadap perjanjian hubungan kerja yang ditandatangani dan batas waktu perjanjian tersebut antara pekerja alih daya dengan perusahaan penyedia jasa pekerja, apabila perjanjian hubungan kerja dilakukan dengan waktu tertentu dan masih terikat kontrak atau sifat pekerjaannya yang terus-menerus. Hak-hak tersebut akan tetap menjadi utang harta pailit, dimana upah pekerja merupakan salah satu dari piutang yang di istimewakan dan jelas bahwa pekerja yang belum memperoleh bayaran atas upah dan hak-hak lain (seperti pesangon, uang penghargaan, dan lain-lainnya) dari debitur pailit merupakan kreditor preferen (kreditor yang mempunyai hak yang istimewa) (Jono, 2010:121).

Ada beberapa golongan yang mendapatkan pembagian harta pailit dari kurator, dan salah satunya ialah pekerja yang termasuk golongan istimewa atau privilege yaitu kreditur yang memperoleh pembayaran terlebih dahulu dari hasil harta penjualan yang sedang mengalami keadaan pailit. Dan disamping itu ada beberapa kreditor yang lainnya yang mempunyai hak untuk mendapatkan hasil penyelesaian harta pailit, yaitu: Pertama, Golongan khusus: kreditur yang mempunyai hak tanggungan gadai atau hak agunan atas kebendaan lainya dapat mengeksekusi haknya seolah-olah tidak terjadi kepailitan; Kedua, Golongan istimewa atau privilege: kreditur yang mempunyai kedudukan istimewa, kreditur yang hak pelunasan terlebih dahulu atas penjualan harta pailit; Ketiga, Golongan konkuren: tidak termasuk semua golongan melainkan pelunasan utang mereka dicukupkan dengan sisa hasil pelelangan harta pailit sesudah diambil oleh golongan yang lain dibagi menurut proporsi masingmasing yang sudah diatur dalam Pasal 1132 BW (Marbun D.C., 2010:3).

Pembagian harta pailit akan dilakukan oleh kurator yang mempunyai tugas untuk melakukan pemberesan harta pailit dan dalam pelaksanaannya diawasi oleh 
hakim pengawas. Sehubungan dengan harta pailit dari Perusahaan Penyedia Jasa Pekerja pemberesan harta yang dilakukan oleh kurator ditujukan kepada pekerja alih daya yang dilakukan pemutusan hubungan kerja oleh perusahaan. Ada beberapa pekerja yang diperbolehkan oleh UU Ketenagakerjaan yang dapat dilakukan PHK, yaitu:

Pertama, Pasal 160 ayat (3) menyatakan bahwa pengusaha dapat melakukan PHK terhadap pekerja atau buruh yang setelah 6 (enam) bulan tidak dapat melakukan pekerjaan sebagaimana mestinya karena proses perkara pidana;

Kedua, Pasal 161 ayat (1) menyatakan, dalam hal pekerja melakukan pelanggaran ketentuan yang diatur dalam Perjanjian Kerja, Peraturan Perusahaan, atau Perjanjian Kerja Bersama, pengusaha dapat melakukan PHK setelah pekerja yang bersangkutan diberikan surat peringatan pertama, kedua dan ketiga secara berturut turut;

Ketiga, Pasal 163 ayat (1) menyatakan bahwa pengusaha dapat melakukan PHK terhadap pekerja atau buruh dalam hal terjadi perubahan status, penggabungan, peleburan, atau perubahan kepemilikan perusahaan dan pekerja atau buruh tidak bersedia melanjutkan hubungan kerja;

Keempat, Pasal 163 ayat (2) menyatakan bahwa pengusaha dapat melakukan PHK terhadap pekerja atau buruh dalam hal terjadi perubahan status, penggabungan, peleburan, atau perubahan kepemilikan perusahaan dan pengusaha tidak bersedia melanjutkan hubungan kerja;

Kelima, Pasal 164 ayat (1) yang menyatakan bahwa pengusaha dapat melakukan PHK terhadap pekerja atau buruh karena perusahaan tutup yang disebabkan perusahaan mengalami kerugian secara terus-menerus;

Keenam, Pasal 165 ayat (1) yang menyatakan bahwa pengusaha dapat melakukan PHK dikarenakan perusahaan pailit;

Ketujuh, Pasal 167 ayat (1) yang menyatakan bahwa pengusaha dapat melakukan PHK dikarenakan pekerja memasuki usia pensiun.

Perusahaan jasa pekerja yang mengalami keadaan pailit yang masih mempunyai pekerja alih daya sebagaimana Pasal 59 ayat (1) atau Pasal 60 ayat (1). Maka pekerja alih daya dimaksud sebagaimana Pasal 165 UU Ketenagakerjaan jo Pasal 39 UU Kepailitan, menyatakan bahwa apabila ada pemutusan hubungan kerja kurator tetap berpedoman pada peraturan perundang-undangan di bidang ketenagakerjaan (Jono, 2010:116). Dan adanya Putusan MK No. 27/ PUU-IX/2011 tentang Sistem Pekerja Alih Daya akan memperkuat kedudukan hukum terhadap status pekerja alih daya dimaksud, apabila perusahan penyedia jasa pekerja mengalami keadaan pailit, pekerja akan tetap mendapatkan perlindungan hak-hak sebagaimana yang diatur oleh undang-undang.

UU Kepailitan sebagaimana Pasal 39 ayat (1) dan (2), yang mengatur hubungan kerja bahwa PHK pada saat debitur atau pengusaha mengalami keadaan pailit baik pemutusan tersebut disebabkan inisiatif dari pekerja sendiri maupun dari pengusaha harus mengindahkan jangka waktu untuk melakukan penghentian pekerja paling singkat 45 hari sebelumnya (Jono, 2010:118), Dalam waktu dimaksud kurator telah mempersiapkan beberapa hal untuk menyelesaikan pemberesan harta pailit yang salah satunya diberikan kepada pekerja alih daya.

Perusahaan penyedia jasa pekerja yang mengalami keadaan pailit merupakan suatu keadaan yang mana debitur tidak mampu lagi untuk melakukan pembayaranpembayaran terhadap utang dari para krediturnya. Karena adanya kesulitan yang dihadapi, sehingga mengalami kesulitan untuk membayar upah pekerja alih daya dan perusahaan penyedia jasa pekerja belum dapat memberikan hak pekerja sesuai waktu yang telah disepakati dalam perjanjian kerja, dalam keadaan pailit tersebut perusahaan dapat melakukan PHK terhadap pekerja alih daya, dengan ketentuan pekerja masih berhak atas uang pesangon sebesar 1 kali ketentuan Pasal 156 ayat (2), uang penghargaan masa kerja sebesar 1 kali ketentuan Pasal 156 ayat (3) dan uang penggantian hak sesuai ketentuan Pasal 156 ayat (4) UU Ketenagakerjaan (Jono, 2010:119). Hal ini juga selaras dengan putusannya MK No. 27/PUUIX/2011 tentang Sistem Alih Daya yaitu, menurut Mahkamah, pekerja atau buruh yang melaksanakan pekerjaan dalam perusahaan alih daya tidak boleh kehilangan hak-haknya yang dilindungi oleh konstitusi. Untuk itu, Mahkamah harus memastikan bahwa hubungan kerja antara pekerja dengan perusahaan alih daya yang melaksanakan pekerjaan alih daya dilaksanakan dengan tetap menjamin perlindungan atas hak-hak pekerja, dan penggunaan model alih daya tidak disalahgunakan oleh perusahaan hanya untuk kepentingan dan keuntungan perusahaan tanpa memperhatikan, bahkan mengorbankan hak-hak pekerja. Menurut penulis pekerja alih daya yang terkena PHK 
oleh perusahaan penyedia jasa pekerja yang mengalami keadaan pailit status pekerja tersebut putus tetapi tetap mendapatkan hak-hak pekerja sebagaimana mestinya, dalam Pasal 28-30 PerMenTrans No. 19 Tahun 2012 tentang Syarat-syarat Penyerahan Sebagian Pelaksanaan Pekerjaan Kepada Perusahaan Lain.

Perusahaan penyedia jasa pekerja yang mengalihkan perjanjian kerjanya kepada perusahaan penyedia jasa pekerja yang lain pun masih tetap untuk memenuhi hak-hak pekerja alih daya sebagaimana pertimbangan Putusan MK No. 27/PUU-IX/2011 tentang Sistem Pekerja Alih Daya yaitu hubungan kerja antara pekerja dengan perusahaan yang melakukan pekerjaan alih daya berdasarkan PKWT, maka pekerja harus tetap mendapat perlindungan atas hak-haknya sebagai pekerja dengan menerapkan prinsip pengalihan tindakan perlindungan bagi pekerja atau buruh (Transfer of Undertaking Protection of Employment atau TUPE) yang bekerja pada perusahaan yang melaksanakan pekerjaan outsourcing.

Dalam praktik, prinsip tersebut telah diterapkan dalam hukum ketenagakerjaan, yaitu dalam hal suatu perusahaan diambil alih oleh perusahaan lain. Untuk melindungi hak-hak para pekerja yang perusahaannya diambil alih oleh perusahaan lain, hak-hak dari pekerja dari perusahaan yang diambil alih tetap dilindungi. Pengalihan perlindungan pekerja diterapkan untuk melindungi para pekerja alih daya dari kesewenangwenangan pihak pemberi kerja atau pengusaha. Dengan menerapkan prinsip pengalihan perlindungan, ketika perusahaan pemberi kerja tidak lagi memberikan pekerjaan borongan atau penyediaan jasa pekerja kepada suatu perusahaan alih daya yang lama dan memberikan pekerjaan tersebut kepada perusahaan alih daya yang baru, maka selama pekerjaan yang diperintahkan untuk dikerjakan masih ada dan berlanjut, perusahaan penyedia jasa baru tersebut harus melanjutkan kontrak kerja yang telah ada sebelumnya, tanpa mengubah ketentuan yang ada dalam kontrak, tanpa persetujuan pihak-pihak yang berkepentingan, kecuali perubahan untuk meningkatkan keuntungan bagi pekerja karena bertambahnya pengalaman dan masa kerjanya.

Menurut Putusan MK tersebut bahwa pengalihan pekerja alih daya kepada perusahaan penyedia jasa pekerja yang baru tidak akan menghilangkan terhadap hak-hak pekerja alih daya begitu saja dan perusahaan penyedia jasa pekerja tetap harus bertanggungjawab kepada pekerja alih daya yang ada di bawah naungannya sebelumnya, meskipun telah diketahui bahwa hak dan kewajiban yang diberikan oleh perusahaan penyedia jasa pekerja kepada pekerja alih daya dengan hak dan kewajiban yang diberikan oleh perusahaan pemberi kerja sifat pekerjaanya tetapi hubungan hukumnya berbeda, hal ini disesuaikan dengan perjanjian yang ditandatangani oleh kedua belah pihak, di dalam suatu perjanjian yang sudah diatur di dalam Pasal 52 ayat (1) UU Ketenagakerjaan yang menunjukan suatu perbuatan hukum yang dilakukan oleh satu orang atau lebih untuk mengikatkan dirinya dengan orang lain untuk mencapai suatu tujuan tertentu. Bilamana suatu perusahaan penyedia jasa pekerja yang mengalami keadaan pailit atau bangkrut, maka perjanjian antara pekerja alih daya dengan perusahaan penyedia jasa pekerja tidak otomatis akan berakhir, meskipun perjanjian antara penyedia jasa pekerja dengan pemberi kerja terhadap MoU yang sudah ditandatangani dapat berakhir karena sudah tidak sanggup lagi mengelola pekerja alih daya dengan mengalihkan kepada perusahaan penyedia jasa pekerja yang lain. Tetapi pemberi kerja dapat juga melakukan gugatan kepada perusahaan penyedia jasa pekerja yang mengalami keadaan pailit tersebut karena perjanjian MoU yang telah ditandatangani tidak diselesaikan hingga batas yang telah ditentukan oleh kedua belah pihak, sehingga menimbulkan suatu kerugian kepada pemberi kerja sebagaimana Pasal 1338 BW jo Pasal 1865 BW menunjukan perjanjian tersebut tidak dapat diputus secara sepihak oleh salah satu pihak, pemberi kerja harus membuktikan bahwa perjanjian MoU tidak dijalankan secara itikat baik oleh perusahaan penyedia jasa pekerja untuk mengganti kerugian kepada perusahaan pemberi kerja.

Pengakhiran MoU oleh perusahaan pemberi kerja kepada perusahaan penyedia jasa pekerja menyangkut pembayaran dan fee terhadap penempatan tenaga kerja untuk mendapatkan pekerja yang diinginkan. Kewajiban perusahaan penyedia jasa pekerja harus bertanggungjawab terhadap perusahaan pemberi kerja: 1. Menyediakan tenaga kerja sesuai dengan permintaan pemberi kerja; 2. Memberikan peringatan tertulis kepada pihak pemberi kerja terhadap jangka waktu penggunaan tenaga kerja; 3 . Mengajukan surat perpanjangan kontrak; 4. Menyediakan absensi bagi tenaga kerja; 5. Menjaga kerahasiaan pihak pemberi kerja; dan 6. Menghitung dan membayar upah, pajak, transport, dan lain-lain terkait dengan tenaga kerja yang dipekerjakan. 
Status hukum pekerja alih daya bila perusahaan penyedia jasa pekerja yang mengalami keadaan pailit harus didasarkan Pasal 165 UU Ketenagakerjaan terhadap perjanjian yang sudah disepakati oleh pekerja alih daya dengan perusahaan penyedia jasa pekerja, berdasar Pasal 59 UU Ketenagakerjaan hak-hak para pekerja alih daya tidak mendapatkan pengganti apapun dari perusahaan penyedia jasa pekerja yang mengalami keadaan pailit bila perjanjian yang ditandatangani sudah jatuh tempo pada saat perusahaan mengalami pailit sebagaimana Pasal 59 ayat (1) huruf b dan status pekerja alih daya akan berakhir demi hukum. Dan apabila pekerja alih daya diberhentikan pada masa kontrak disebabkan perusahaan penyedia jasa pekerja mengalami keadaan pailit, perusahaan penyedia jasa pekerja wajib mengganti/membayar atau menanggung sisa kontrak dengan pekerja alih daya sebagaimana Pasal 62 UU Ketenagakerjaan dan status hukum pekerja alih daya masih menjadi pekerja hingga mencapai batas waktu perjanjian kontrak kerjanya yang telah ditandatangani. Tetapi bagi pekerja alih daya sebagaimana Pasal 60 UU Ketenagakerjaan maka perusahaan penyedia jasa pekerja masih terikat perjanjian dengan pekerja alih daya bila diberhentikan harus memberikan hak-hak sebagaimana Pasal 156 ayat (1), (2) dan (3).

\section{Penyelesaian Pekerja Alih Daya di Perusahaan Penyedia Jasa}

Sejak dilegalkan penyerahan pekerja kepada perusahaan lain sebagaimana diatur Pasal 64 UU Ketenagakerjaan, maka hampir semua sektor usaha yang ada menerapkan dan menempatkan pekerja melalui perusahaan penyedia jasa pekerja, banyaknya permintaan pekerja dari perusahaan pemberi kerja membawa pengaruh besar terhadap berdirinya perusahaan-perusahaan penyedia jasa pekerja yang sekian lama tambah banyak bermunculan yang mengajukan izin kepada pihak Dinas Tenaga Kerja, baik di desa maupun di kota, baik di pinggiran kota maupun di tengah kota. Banyaknya pendirian perusahaan-perusahaan penyedia jasa pekerja tersebut disebabkan banyaknya permintaan terhadap pekerja terutama pekerja alih daya dari tahun ke tahun, baik permintaan terhadap perusahaan penyedia jasa pekerja yang mempunyai izin resmi maupun yang tidak mempunyai izin, tetapi kenyataannya tetap sama-sama eksis dalam menempatkan tenaga kerja bahkan keberadaannya terus ada dan diterima oleh perusahaan pemberi kerja, permintaan penempatan pekerja dari perusahaan penyedia jasa pekerja yang tidak mempunyai izin tersebut banyak menimbulkan ketidakberesan atau dari beberapa perusahaan penyedia jasa pekerja melakukan persaingan yang tidak sehat antar perusahaan penyedia jasa pekerja dan pada akhirnya dibuat suatu kesempatan oleh perusahaan pemberi kerja untuk menerima pekerja alih daya dan ujung-ujungnya yang menjadi korban pekerja alih daya yang tidak tahu-menahu apa yang terjadi antara perusahaan pemberi kerja dengan perusahaan penyedia jasa pekerja. Persaingan tidak sehat tersebut semakin lama semakin meruncing dan menyebabkan yang menjadi korban pekerja alih daya dengan tidak diberikannya perlindungan hukum terhadap hakhaknya yang semestinya diterima sesuai ketentuan UU Ketenagakerjaan. Bahkan adakalanya perusahaan penyedia jasa pekerja siap-siap menanggung rugi karena pengelolaan terhadap pekerja alih daya yang ditempatkan tidak sehat dengan melakukan banting harga.

Penempatan pekerja alih daya sebagaimana Pasal 64 UU Ketenagakerjaan merupakan payung hukum bagi perusahaan penyedia jasa pekerja untuk menempatkan pekerja alih daya dan bila perusahaan penyedia jasa mengalami keadaan pailit dan tidak bisa melanjutkan kontrak kerja dengan perusahaan pemberi kerja maupun dengan pekerja alih daya meskipun perjanjian hubungan kerja dilakukan antara pekerja alih daya dengan perusahaan penyedia jasa pekerja sebagaimana Pasal 59, 60 dan $62 \mathrm{UU}$ Ketenagakerjaan. Maka perusahaan penyedia jasa pekerja yang mengalami keadaan pailit harus tetap tunduk dan menyelesaikan sebagaimana Putusan MK No. 27/PUU-IX/2011 tentang Sistem Pekerja Alih Daya, meskipun perusahaan penyedia jasa pekerja tidak diperpanjang kontraknya oleh perusahaan pemberi kerja atau perusahaan penyedia jasa yang baru menerima pekerja alih daya dari perusahaan penyedia jasa yang lama.

Terdapat 2 (dua) model untuk melakukan penyelesaian atau perlindungan terhadap pekerja alih daya yaitu: Pertama, dengan mensyaratkan agar perjanjian kerja antara pekerja/buruh dengan perusahaan yang melaksanakan pekerjaan alih daya tidak berbentuk PKWT melainkan berbentuk Perjanjian Kerja Waktu Tidak Tertentu. Kedua, menerapkan prinsip pengalihan tindakan perlindungan bagi pekerja atau buruh (Transfer of Undertaking Protection of 
Employment atau TUPE) yang bekerja pada perusahaan yang melaksanakan pekerjaan alih daya.

Pasal 155 ayat (2) selama belum ada putusan dari Pengadilan Industrial pengusaha dan pekerja tetap menjalankan kewajiban dan mendapatkan hak-hanya sebagaimana yang telah disepakati atau undang-undang, menurut penulis semua elemen yang terkait dalam sistem pekerja alih daya sebelum adanya kesepakatan atau putusan dari Pengadilan Hubungan Industrial, perjanjian kerja yang telah disepakati itu tetap ada dan dilaksanakan sebagaimana mestinya, dan dalam pasal tersebut menunjukan perusahaan yang mengalami keadaan pailit atau bangkrut masih tetap mempunyai kewajiban sampai mempunyai kekuatan hukum yang tetap. Pasal 155 ayat (2) ini jo Pasal 156 ayat (2), (3) dan (4) yang mengatur tentang hakhak pekerja alih daya selama bekerja di perusahaan penyedia jasa pekerja. Serta dalam Pasal 157 ayat (1) dimana semua komponen yang terdapat di dalam uang pesangon atas dasar upah pokok, tunjangan yang bersifat tetap terhadap pekerja alih daya.

Menurut penulis ketentuan peraturan perundangundangan sudah dijelaskan mengenai hak dan kewajiban terhadap pekerja alih daya serta hak dan kewajiban terhadap perusahaan penyedia jasa pekerja, namun dalam penerapannya seringkali tidak sesuai dengan apa yang ada di dalam UU Ketenagakerjaan, sehingga di keadaan di lapangan sangat kontras berbeda sekali terhadap pekerja alih daya tersebut, apabila perusahaan penyedia jasa pekerja mengalami kesulitan atau bahkan sampai mengalami keadaan pailit akhirnya ujung-ujungnya yang dipersalahkan atau yang menjadi korban pertama kali pekerja alih daya, sehingga pekerja alih daya yang seharusnya mendapatkan perlindungan hukum yang pertama terhadapat hak-hak yang harus diterima tetapi kenyataannya tidak mendapatkan apa-apa kecuali hanya mendapatkan sehelai kertas bahwa pekerja alih daya telah bekerja di perusahaan penyedia jasa pekerja dengan baik selama bekerja dalam kata lain hanya referensi kerja, padahal yang diharapkan oleh pekerja alih daya bukan referensi kerja tetapi upah pekerja yang belum diterima dan hak-hak lainnya, dan hal ini sudah jelas di dalam hukum kepailitan pekerja alih daya atau pekerja lainnya yang berkedudukan sebagai kreditur privilege atau diistimewakan harus mendapatkan hak-hak yang harus diterima sesuai peraturan perundang-undangan yang berlaku saat ini.
Perusahaan penyedia jasa pekerja disamping harus mendaftarkan para pekerjanya kepada Badan Penyelenggara Jasa Sosial (selanjutnya disebut BPJS) sebagai perlindungan terhadap pekerja alih daya, juga bila terjadi PHK di perusahaan tersebut tidak menghapuskan terhadap pengusaha untuk memberikan hak-haknya termasuk uang pesangon kepada pekerja yang harus diterima, dengan didaftarkannya pekerja alih daya kepada BPJS tentu para pekerja alih daya sangat terbantu untuk melindungi diri pribadi pekerja dan keluarganya sambil menunggu hak-haknya sebagai pekerja sebagaimana yang disebutkan di dalam Pasal 155-157 UU Ketenagakerjaan dipenuhi oleh perusahaan penyedia jasa pekerja. Serta dalam Pasal 65 ayat (4) UU Ketenagakerjaan mengatur syarat-syarat kerja yang diberikan kepada pekerja alih daya kemudian diatur dalam Pasal 3 dan Pasal 9 PerMenTrans No. 19 Tahun 2012 tentang Syarat-syarat Penyerahan Sebagian Pelaksanaan Pekerjaan kepada Perusahaan Lain, di dalam Pasal 9 ayat (2) dinyatakan suatu perjanjian pemborongan harus memuat sekurang-kurangnya hak dan kewajiban masing masing pihak, menjamin terpenuhinya perlindungan kerja dan syarat-syarat kerja bagi pekerja buruh, dan memiliki tenaga kerja yang mempunyai kompetensi di bidangnya. Dalam Pasal 65 ayat (4) UU Ketenagakerjaan juga mensyaratkan bahwa perlindungan pekerja alih daya termasuk keselamatan kerja, pengupahan yang diatur dengan semaksimal mungkin dan kesejahteraan yang juga harus dirasakan oleh pekerja alih daya.

Sistem Jaminan Sosial Nasional telah memberikan perlindungan lebih luas bukan hanya kepada tenaga kerja saja tetapi seluruh Warga Negara Indonesia harus diberikan perlindungan kesehatan, tidak terkecuali bagi perusahaan penyedia jasa pekerja harus memberikan perlindungan kepada pekerjanya dalam hal program kematian dan hari tua, namun dengan diberlakukannya UU BPJS Ketenagakerjaan sifat perlindungan kepada pekerja lebih luas karena sudah ada pengelolaannya pada lembaga negara yang menangani dan bertanggungjawab secara langsung kepada Presiden, sangat berbeda dengan perlindungan kepada pekerja yang diatur UU Jamsostek sebelumnya seperti: Pertama, Secara kelembagaan pengelolaan Jamsostek dilakukan oleh perusahaan negara yakni PT Jamsostek. Bentuk ini memiliki kelemahan karena PT bermotif mencari keuntungan (provit oriented), padahal jaminan sosial tenaga kerja merupan bentuk perlindungan sosial melalui sistem asuransi sosial; 
Kedua, Saat ini saham Jamsostek 100\% dikuasai oleh pemerintah padahal sumber keuangan dari iuran pekerja dan pengusaha. Akibatnya semua keuntungan perusahaan (deviden) dinikmati oleh pemerintah, bukan oleh pekerja sebagai sumber keuangannya. Keuntungan Jamsostek yang sangat besar semestinya dikembalikan kepada pekerja melalui tunjangan PHK, perumahan, dan pinjaman lunak untuk modal usaha istri dan suami pekerja (Lalu Husni, 2012: 210-211)

Pasal 155-157 UU Ketenagakerjaan, terhadap pengaturan terhadap pekerja untuk mendapatkan hak-haknya sebagai pekerja yang terkena PHK, pasal di atas diberi pengaturan lebih lanjut kepada pekerja yang merasa hak-hak belum terlindungi yaitu dengan adanya Undang-Undang Nomor 2 Tahun 2004 tentang PPHI (selanjutnya disingkat UU PPHI) maka pengaturan tentang penyelesaian hubungan industrial yang belum selesai secara musyawarah karena belum puas terhadap penyelesaian menggunakan Pasal 3-5 dengan cara bipartit yang disepakati oleh semua pihak untuk mencapai suatu hasil yang lebih baik sebelum melangkah ke dalam perundingan mediasi, konsiliasi maupun arbitrase, bila hal ini belum mencapai suatu kesepakatan maka jalan satu-satunya harus menempuh PPHI yang harus memasukan gugatan kepada salah satu pihak. Menurut pendapat para ahli penyelesaian secara bipartid, yaitu musyawarah antara pekerja dan pengusaha. Apabila tidak mencapai kesepakatan dengan cara bipartid, maka pihak-pihak dapat memilih penyelesaian secara mediasi, konsiliasi, atau arbitrase. Apabila para pihak memilih mediasi atau konsiliasi dan tidak mencapai kesepakatan, dapat membawa perkaranya ke Pengadilan Hubungan Industrial. Apabila pihak-pihak memilih arbitrase maka kesepakatan dituangkan dalam akta perdamaian yang merupakan keputusan arbitrase dan harus didaftarkan ke Pengadilan Negeri (Asri Wijayanti, 2005:167). Menurut penulis di dalam UU PPHI sudah mencakup semua aspek untuk penyelesaian ketenagakerjaan di Indonesia sebelum mengajukan gugatan di PPHI, PHI menawarkan penyelesaian yang lebih menitikberatkan kepada kemufakatan atau musyawarah yang dilakukan oleh para pihak yang bersengketa dalam hal ketenagakerjaan.

Penyelesaian sengketa yang disebabkan karena PHK dari perusahaan penyedia jasa pekerja disebabkan mengalami keadaan pailit harus benar-benar sesuai dengan peraturan yang berlaku agar perusahaan benar-benar memberikan perlindungan hukum kepada pekerja alih daya. PHK ini sebenarnya merupakan akibat dari adanya sengketa antara buruh dan majikan yang berlanjut sampai proses pengadilan. Datangnya perkara dapat dari pekerja atau dari perusahaan. Bentuknya dapat meminta ganti rugi ke Pengadilan Negeri apabila diduga melanggar hukum dari salah satu pihak atau dapat melalui Pengadilan Hubungan Industrial (Asri Wijayanti, 2005:167).

UU PPHI sudah mengatur untuk mencapai suatu kemufakatan dalam PHK kepada pekerja alih daya bila tidak sesuai dengan peraturan yang semestinya, meskipun aturan sudah jelas tetapi masih banyak para aktifis tenaga kerja yang tetap tidak terima atau tidak menginginkan keberadaan pekerja alih daya. Putusan MK No. 27/PUU-IX/2011 tentang Pekerja Alih Daya yang banyak berkaitan dengan PKWT dan peralihan hak atau prinsip pengalihan tindakan perlindungan dalam pekerja alih daya, amar Putusan MK mempertahankan dua bentuk hubungan kerja yang salama ini dikenal dalam UU Ketenagakerjaan karena tidak bertentangan dengan UUD, yakni PKWT dan PKWTT. Penegasan lain dari putusan MK adalah memperkenalkan sekaligus membolehkan dua macam PKWT, yaitu PKWT bersyarat dan PKWT tidak bersyarat. Termasuk PKWT bersyarat adalah PKWT yang mengharuskan perusahaan penyedia jasa pekerja mensyaratkan pengalihan perlindungan hak-hak bagi pekerja apabila objek kerjanya tetap ada meskipun perusahaan pemborong pekerjaan atau perusahaan penyedia jasa pekerja diganti. Adapun PKWT tanpa syarat adalah PKWT yang dilaksanakan tanpa mensyaratkan adanya pengalihan hak-hak bagi pekerja sebagaimana disebutkan (www.hukumonline.com).

Hak-hak dan kewajiban yang melekat pada setiap elemen dalam sistem kerjasama alih daya yaitu: Pertama, Hak dan Kewajiban Pekerja. Hak-hak pekerja yang telah diatur dalam UU Ketenagakerjaan merupakan tanggung jawab pihak perusahaan penyedia jasa pekerja. Adapun hak-hak pekerja secara umum diatur dalam pasal sebagai berikut: 1. Pasal 86 UU Ketenagakerjaan, menyatakan bahwa setiap pekerja mempunyai hak untuk memperoleh perlindungan atas: Keselamatan dan kesehatan kerja; Moral dan kesusilaan; serta Perlakuan yang sesuai dengan harkat dan martabat manusia serta nilai agama; 2 . Pasal 88 UU Ketenagakerjaan menyatakan bahwa setiap pekerja berhak memperoleh penghasilan yang memenuhi penghidupan yang layak bagi kemanusiaan; 3. Pasal 99 UU Ketenagakerjaan yang menyatakan bahwa setiap pekerja dan keluarganya berhak untuk 
memperoleh jaminan sosial tenaga kerja; 4. Pasal 156 UU Ketenagakerjaan yang menyatakan bahwa setiap pekerja yang di PHK berhak mendapatkan uang pesangon; 5. Pasal 162 UU Ketenagakerjaan yang secara garis besar menyebutkan bahwa setiap pekerja yang mengundurkan diri karena keinginan sendiri berhak mendapatkan uang penggantian hak.

Sedangkan kewajiban pekerja alih daya yang paling utama harus melakukan pekerjaan sesuai dengan perjanjian kerja yang telah ditandatangani. Pekerjaan harus dikerjakan sendiri karena melakukan pekerjaan itu bersifat kepribadian, artinya kerja itu melekat pada diri pribadi, sehingga apabila pekerja meninggal dunia, hubungan kerja berakhir demi hukum. Oleh karena itu pekerjaan tidak bisa diwakilkan atau diwariskan (Djumialdji, 2005:42), dan selain itu pekerja wajib menaati semua tata tertib yang telah diatur oleh perusahaan tanpa terkecuali asalkan tata tertib tidak melanggar UU Ketenagakerjaan dan hak-hak pekerja.

Kedua, Hak dan Kewajiban Pemberi Kerja. Hak pemberi kerja dalam perjanjian hubungan kerja sistem alih daya untuk mendapatkan pekerja sesuai dengan kriteria yang diinginkan pihak perusahaan, disamping itu pihak perusahaan berhak melakukan PHK dengan pekerja dengan syarat-syarat yang diperbolehkan oleh undang-undang. Kewajiban pemberi kerja merupakan hak bagi pekerja, yaitu wajib: 1. Memberikan upah pekerja yang layak, sesuai dengan kinerja pekerja dan peraturan perundangan yang berlaku; 2 . Memberi waktu istirahat dan hari libur resmi, sebagaimana diatur dalam paragraf 4 bagian kesatu Bab X UU Ketenagakerjaan; 3. Mengatur tempat kerja dan alat kerja, hal ini merupakan kewajiban yang diadakan agar kecelakaan kerja pada pekerja dapat dihindari; 4. Bertindak sebagai pengusaha yang baik, meskipun kewajiban ini tidak tertulis dalam perjanjian kerja, namun hal ini merupakan kepatutan atau kebiasaan, sesuai dengan akibat perjanjian yang diatur dalam Pasal 1339 KUHPerdata yang menyatakan bahwa perjanjian tidak hanya mengikat untuk hal-hal yang tegas dinyatakan didalamnya, tetapi juga untuk segala sesuatu menurut sifatnya perjanjian diharuskan oleh kepatutan, kebiasaan, atau undang-undang; 5. Memberi surat keterangan kerja, di dalam praktek, pengusaha memberikan surat keterangan (referensi) tentang pekerjaan pekerja atau buruh sewaktu hubungan kerja antara pekerja atau buruh dengan pengusaha telah berakhir (Djumialdi, 2005:41).
Pasal 35 ayat (3) UU Ketenagakerjaan menyatakan, pemberi kerja dalam memperkerjakan tenaga kerja wajib memberikan perlingungan yang mencakup kesejahteraan, keselamatan, dan kesehatan, baik mental maupun fisik pekerja. Dalam pelaksanaan alih daya sering menimbulkan berbagai potensi yang menyebabkan terjadinya perselisihan yang mungkin timbul, misalnya; pelanggaran terhadap peraturan perusahaan oleh pekerja maupun adanya kecemburuan antara pekerja yang menimbulkan perselisihan antara pekerja alih daya dengan pekerja lainnya. Menurut Pasal 66 ayat (2) huruf c UU Ketenagakerjaan, penyelesaian perselisihan yang timbul menjadi tanggung jawab perusahaan penyedia jasa pekerja. Jadi, walaupun terjadinya pelanggaran yang dilakukan oleh pekerja alih daya terhadap peraturan yang ada di perusahaan pemberi kerja, kewenangan untuk menyelesaikan permasalahan tersebut adalah tetap berada pada perusahaan penyedia jasa pekerja. Dalam hal ini perusahaan penyedia jasa pekerja harus dapat menempatkan diri dan bersikap bijaksana sehingga dapat mengakomodasi terhadap kepentingan pekerja dengan perusahaan pemberi kerja, disebabkan perusahaan pemberi kerja yang terlibat secara langsung terhadap pekerja alih daya yang ditempatkan oleh perusahaan jasa pekerja karena pemberi kerja dapat memerintah secara langsung kepada pekerja alih daya. Meskipun demikian perusahaan penyedia jasa pekerja secara berkala akan selalu mengawasi terhadap pekerja alih daya yang ditempatkan di perusahaan pemberi kerja untuk mengurangi potensi-potensi yang dapat menimbulkan komplek dan menimbulkan pelanggaran yang dilakukan oleh pekerja alih daya.

Pemecatan atau PHK terhadap pekerja alih daya yang dilakukan oleh perusahaan pemberi kerja, tidak berakibat putusnya kepada perjanjian hubungan kerja yang telah ditandatangani antara pekerja alih daya dengan perusahaan penyedia jasa pekerja, terkecuali dalam perjanjian hubungan kerja yang telah ditandatangi tersebut terdapat klausula di dalam perjanjian yang telah ditandatangani yang menyebutkan putusnya hubungan kerja dari perusahaan pemberi kerja akan mengakibatkan putusnya juga terhadap perjanjian hubungan kerja kepada perusahaan penyedia jasa pekerja dengan pekerja alih daya. Tetapi bila dalam perjanjian hubungan kerja antara pekerja alih daya dengan perusahaan penyedia jasa pekerja tidak menyebutkan akibat terjadinya putusnya hubungan kerja terhadap pekerja alih daya dengan perusahaan pemberi 
kerja meskipun putusnya MoU dengan perusahaan pemberi kerja yang diberikan ada beberapa alasan, maka pekerja alih daya tetap masih menjadi pekerja dari perusahaan penyedia jasa pekerja di tempat dia bernaung atau sesuai dengan batas waktu perjanjian yang telah ditandatangani dan perusahaan pemberi kerja tidak mempunyai kewajiban untuk memberikan ganti rugi apapun kepada pekerja alih daya.

Pasal 66 ayat (2) huruf c yang menyatakan bahwa perlindungan upah dan kesejahteraan, syarat kerja dan perselisihan yang timbul menjadi tanggung jawab perusahaan penyedia jasa, sehingga hubungan pekerja alih daya dengan perusahaan pemberi kerja hanya sebatas hubungan secara tidak langsung, dan secara hukum pekerja alih daya bukan pekerja dari perusahaan pemberi kerja, sehingga apabila perusahaan pemberi kerja sudah tidak membutuhkan lagi terhadap pekerja alih daya dengan alasan apapun sepanjang tidak menyebutkan alasan-alasan yang diperbolehkan kepada perusahaan pemberi kerja untuk mengembalikan pekerja alih daya di dalam MoU antara perusahaan pemberi kerja dengan perusahaan penyedia jasa pekerja, maka pekerja alih daya dapat 'dikembalikan' ke perusahaan penyedia jasa yang dinaungi. Di dalam perjanjian antara pekerja alih daya dan perusahaan penyedia jasa pekerja harus mengacu pada Pasal 59 UU Ketenagakerjaan terhadap syarat-syarat yang diperbolehkan dalam PKWT, apabila di kemudian hari adanya suatu pemberhentian di tengah kontrak baik terhadap perusahaan penyedia jasa kerja maupun pemberhentian di tengah kontrak terhadap pihak pekerja alih daya, dan Pasal 62 UU Ketenagakerjaan yang mengatur tentang PHK sebelum waktu yang sudah disepakati oleh kedua belah pihak. Serta Pasal 60 UU Ketenagakerjaan terhadap pekerja alih daya yang diangkat sebagai pekerja tetap sejak awal melakukan perjanjian hubungan kerja.

Putusan MK No. 27/PUU-IX/2011 tentang PKWT untuk Perusahaan Penerima Pemborongan Pekerjaan yang diatur berdasarkan ketentuan Pasal 65 ayat (7) UU Ketenagakerjaan, selain harus memenuhi syarat sebagaimana dimaksud dalam Pasal 59 UU Ketenagakerjaan dan Pasal 28-30 PerMenTrans No. 19 Tahun 2012, juga harus memuat perjanjian yang menyatakan adanya pengalihan perlindungan hak-hak bagi pekerja alih daya dalam hal terjadi pergantian perusahaan penyedia jasa pekerja terhadap pekerja alih daya yang memperkerjakannya, dan dalam Pasal 66 ayat (2) UU Ketenagakerjaan mengatur tentang pekerja alih daya yang dipekerjakan oleh penyedia jasa pekerja kepada pemberi kerja maka PKWT untuk pekerja alih daya harus memenuhi syarat Pasal 59 ayat (1) jo Pasal 52 UU Ketenagakerjaan.

Putusan dari MK juga mengharuskan memuat perjanjian akan adanya pengalihan perlindungan hak-hak bagi pekerja alih daya dalam hal pergantian penyedia jasa pekerja maka penyelesaian yang harus dilakukan oleh penyedia jasa pekerja kepada pekerja alih daya mendapatkan hak-hak sebagai pekerja alih daya dari perusahaan penyedia jasa pekerja bahkan perjanjian tersebut sudah jatuh tempo atau berakhir demi hukum sesuai dengan Pasal 165 sedangkan pekerja alih daya yang direkrut oleh perusahaan pemberi kerja yang mengacu pada Pasal 60 UU Ketenagakerjaan maka penyelesaian yang harus dilakukan terhadap pekerja alih daya oleh penyedia jasa pekerja wajib memberikan pesangon dan uang penghargaan serta penggantian hak yang berpedoman pada Pasal 156 UU Ketenagakerjaan. Tetapi penyelesaian perjanjian hubungan kerja yang mengacu dalam Pasal 62 UU Ketenagakerjaan. Penyelesaian PHK kepada pekerja alih daya oleh perusahaan penyedia jasa pekerja dengan melakukan pembayaran ganti rugi kepada pekerja alih daya yang masih dalam masa kontrak, dan hal ini juga tidak terkecuali terhadap perusahaan penyedia jasa yang mengalami pailit harus menyelesaikan pembayaran ganti rugi atau upah kepada pekerja alih daya terhadap sisa kontrak yang belum dilakukan dari akibat putusnya pekerja alih daya pada masa kontrak.

\section{PENUTUP}

\section{Kesimpulan}

Perusahaan penyedia jasa pekerja dalam keadaan pailit atau bangkrut yang menempatkan pekerja alih daya di perusahaan pemberi kerja meskipun dilakukan dengan PKWT apabila diberhentikan sebelum masa kontrak tetap menjadi karyawan perusahaan penyedia jasa pekerja dan tetap mendapatkan perlindungan hukum sebagaimana Pasal $165 \mathrm{UU}$ Ketenagakerjaan jo Putusan MK No. 27/PUU-IX/ 2011 kemudian dipertegas dengan PeMenTrans No. 19 Tahun 2011. Penyelesaian terhadap pekerja alih daya oleh perusahaan penyedia jasa dalam keadaan pekerja pailit harus berpedoman pada Pasal 62 yaitu pekerja harus mendapatkan sebanyak upah sebanyak sisa kontrak dan Pasal 156 UU Ketenagakerjaan yaitu pekerja alih daya akan diberikan uang pesangon, uang penghargaan dan uang penggantian hak bila pekerjaan 
yang sifatnya terus menerus sedangkan pekerja alih daya yang jatuh tempo kontraknya akan berakhir demi hukum.

\section{Rekomendasi:}

Dinas Tenaga Kerja agar benar-benar mengawasi keberadaan Perusahaan Penyedia Jasa Pekerja yang melakukan PHK terhadap tenaga kerja yang disebabkan perusahaan mengalami pailit agar tidak melakukan semena-mena kepada tenaga kerja.

Dinas Tenaga Kerja diharapkan benar-benar berpedoman dan menerapkan pasal-pasal di dalam UU Ketenagakerjaan dalam mengatur PHK bila mengetahui adanya PHK disebabkan Perusahaan Penyedia Jasa Pekerja mengalami pailit agar tenaga kerja benar-benar terlindungi.

\section{DAFTAR PUSTAKA}

Buku:

Djumialdji, F.X. 2005. Perjanjian Kerja. Jakarta: Sinar Grafika.

Jono. 2008. Hukum Kepailitan. Jakarta: Sinar Grafika.

Lalu, Husni. 2012. Pengantar Hukum Ketenagakerjaan Indonesia. Jakarta: Rajawali Pers.

Marbun D.C. 2010. Diktat Hukum Kepailitan. Surabaya.

Rosmanasari, Evi. 2008. Pelaksanaan Perlindungan Hukum terhadap Tenaga Kerja Outsourcing PT Indah Karya Nuansa Indonesia di PT Pertamina Balongan. Universitas Diponegoro: Program Pasca Sarjana.
Sutedi, Adrian. 2009. Hukum Perburuhan. Cet. I. Jakarta: Sinar Grafika.

Oetomo, R. Goenawan. 2004. Pengantar Hukum Perburuhan dan Hukum Perburuhan di Indonesia. Jakarta: Grhadika Binangkit Press.

Wijayanti, Asri. 2005. Hukum ketenagakerjaan Pasca Reformasi. Jakarta: Sinar Grafika.

\section{Peraturan Perundang-Undangan:}

Undang-Undang Nomor 13 Tahun 2003 tentang Ketenagakerjaan.

Undang-Undang Nomor 2 Tahun 2004 tentang PPHI.

Undang-Undang Nomor 37 Tahun 2004 tentang Kepailitan.

Putusan Mahkamah Konstitusi Nomor 27/PUU-IX/ 2011 tentang Outsourcing.

Peraturan Menteri Tenaga Kerja dan Transmigrasi Republik Indonesia Nomor 19 Tahun 2012 tentang Syarat-Syarat Penyerahan Sebagian Pelaksanaan Pekerjaan Kepada Perusahaan Lain.

Surat Edaran Nomor B.31/PHIJSK/I/2012 tentang Pelaksanaan Putusan Mahkamah Konstitusi Nomor 27/PUU-IX/2011 tanggal 17 Januari 2012.

\section{Website:}

http://www.hukumonline.com. legalitas outsourcing pasca putusan MK. diakses tanggal 9 Oktober 2012. 